\title{
Seleksi, Karakterisasi dan Identifikasi Bakteri Pendegradasi 2- (thiocyanomethylthio) benzothiazole (TCMTB)
}

\section{Selection, Charactrization and Identification of 2-(thiocyanomethylthio) benzothiazole (TCMTB) Degrading Bacteria}

\author{
Langkah Sembiring $^{1 *}$, Lela Susilawati ${ }^{1}$, Dwi Suhartanti ${ }^{2}$ \\ ${ }^{1}$ Fakultas Biologi, Universitas Gadjah Mada, Yogyakarta \\ E-mail: Isembiring@yahoo.com *penulis untuk korespondensi \\ ${ }^{2}$ Fakultas MIPA, Universitas Ahmad Dahlan, Yogyakarta
}

\begin{abstract}
The objective of this research was to investigate the capabilities of bacteria isolated from industrial tanning waste to degrade TCMTB. The bacteria was initialy screened, based on their tolerance to various concentration of TCMTB using paper disk method. Then, those strains were further analyzed in terms of their ability to produce ammonia $\left(\mathrm{NH}_{4}{ }^{+}\right)$and sulphate $\left(\mathrm{SO}_{4}{ }^{2-}\right)$. Degradation activity was measured based on remaining residue of TCMTB analyzed using HPLC. The superior strain that showed the highest activity in degradation of TCMTB then were characterized and identified based on phenotypic and 16S rDNA sequence analysis. The result of the experiments showed that four selected strains among seven were choosen based on their high tolerance to various concentration of TCMTB, namely PK1, PK2, PK4 and PK6. All four strains showed the ability to produce ammonia and sulphate but three of which, namely PK2, PK4 and PK6 showed the high capability to degrade TCMTB. One particular strain (PK2) was observed to degrade TCMTB $40.8 \%$ within 7 days, but the others were less than $30 \%$. Based on the phenotypic characteristics and 16S rDNA sequence analysis, the best strains (PK2) was identified to be member of genus Pseudomonas.
\end{abstract}

Key words: biodegradation, TCMTB, industrial tanning waste, PCR, Sequensing

Diterima: 06 Oktober 2007, disetujui: 02 Mei 2008

\section{Pendahuluan}

Senyawa 2-(thiocyanomethylthio) benzothiazole (TCMTB) merupakan bahan aktif fungisida yang digunakan pada proses penyamakan kulit, karena efektif dalam mengendalikan pertumbuhan jamur yang sering ditemukan tumbuh pada kulit samak seperti Aspergillus sp., Penicillium sp. (Yapici dan Karaboz, 1997) dan Paecilomyces sp. (Birbir et al., 1994). Fungisida TCMTB termasuk golongan pestisida organosulfur yang merupakan salah satu derivat benzothiazole. Toksisitas TCMTB dapat membahayakan organisme air terutama ikan sehingga menurunkan kemampuannya berenang (Ewing,
1999). Selain itu TCMTB dapat berakibat fatal pada mamalia, antara lain menyebabkan radang kulit, terbakar, iritasi mata, hidung dan kerongkongan, sesak dada dan mimisan (Hanssen et al., 1991).

Aktivitas bakteri di alam berperan penting dalam proses degradasi TCMTB sehingga menghasilkan senyawa yang lebih aman di lingkungan. Beberapa bakteri yang telah diketahui mampu menggunakan TCMTB sebagai satu-satunya sumber karbon, nitrogen dan energi antara lain kelompok genus Rhodococcus (Gaja dan Knapp, 1997; de Wever et al., 1998; Haroune et al., 2002; Kirouani, 2003) dan Alcaligenes (Junker et al., 1994). Namun jalur degradasi TCMTB oleh 
mikrobia belum diketahui secara terperinci. Pemecahan ini diduga melalui jalur pemecahan ikatan ortho yang membentuk catechol (de wever et al., 1998; Haroune et al., 2002; Kirouani, 2003).

Penelitian ini bertujuan untuk mengetahui kemampuan tujuh isolat bakteri yang diisolasi dari limbah penyamakan kulit dalam mendegradasi TCMTB. Isolat unggul yang diperoleh kemudian dikarakterisasi secara fenotipik dan molekular, dengan analisis sekuen 16 SrDNA.

\section{Metode Penelitian}

\section{Isolat bakteri}

Tujuh isolat yang diuji antara lain PK1, PK2, PK3, PK4, PK5, PK6 dan PK7.

\section{Seleksi isolat berdasarkan toleransinya terhadap TCMTB}

Isolat diuji toleransinya terhadap TCMTB dengan berbagai konsentrasi (20, 30, 40, 50, 60ppm), menggunakan metoda paper disk pada medium NA. Diameter zona jernih yang terbentuk diukur dan tingkat toleransi isolat didasarkan pada pertumbuhan isolat pada konsentrasi paling tinggi dengan ukuran diameter zona paling rendah atau tidak membentuk zona sama sekali. Pada tahapan ini diperoleh isolat terpilih untuk diuji lebih lanjut.

\section{Seleksi penghasilan ammonia dan sulfat}

Kemampuan degradasi isolat terpilih diuji secara tidak langsung dengan analisis produksi $\mathrm{NH}_{4}^{+}$dan $\mathrm{SO}_{4}{ }^{2-}$ pada medium cair minimal (free $\mathrm{SO}_{4}{ }^{2-}$ dan $\mathrm{NH}_{4}{ }^{+}$) dengan menambahkan TCMTB sebagai sumber karbon dan nitrogen baik secara kualitatif maupun kuantitatif berdasarkan metode Weatherburn dan Mainprize (Besse et al., 2001). Medium uji yang telah diinokulasi, diinkubasikan dengan shaker (150 rpm) pada suhu $37^{\circ} \mathrm{C}$. Selama masa inkubasi, secara periodik (24 jam), pertumbuhan bakteri ditentukan dengan berat kering sel. Residu TCMTB dianalisis menggunakan HPLC.

\section{Analisis TCMTB}

Analisis residu TCMTB dilakukan menggunakan HPLC Shimadzu dengan kolom C-18, temperatur kamar, eluen asetonitril: air $(2 / 8, \quad \mathrm{v} / \mathrm{v})$ dengan kecepatan $1 \mathrm{ml} /$ menit. Detektor yang dipakai adalah Shimadzu UVVis $295 \mathrm{~nm}$. Lima ml sampel diambil secara periodik, kemudian disentrifugasi 12000 xg selama 5 menit dan supernatan yang terbentuk dilarutkan dalam 1-2 ml diklorometan, kemudian dielusi dengan metanol dan selanjutnya diinjeksikan pada kolom HPLC.

\section{Karakterisasi dan identifikasi isolat pendegradasi TCMTB}

Isolat pendegradasi TCMTB dikarakterisasi secara fenotipik dan molekular. Karakteristik fenotipik meliputi pengamatan morfologi sel dan koloni, karakter fisiologis dan biokimiawi. Identifikasi isolat berdasarkan karakter fenotipik dilakukan dengan metode profile matching yang mengacu pada Bergey's Manual of Determinative Bacteriology (Holt et al., 1994). Karakteristik molekular dilakukan dengan konstruksi phylogenetic tree berdasarkan sekuen 16S rDNA.

\section{Amplifikasi 16S rDNA}

$\begin{array}{cccr}\text { DNA } & \text { isolat bakteri diisolasi } \\ \text { menggunakan } & \text { Wizard } & \text { Genomic } & \text { DNA }\end{array}$ Purification Kit (Promega). Amplifikasi 16S rDNA menggunakan metoda PCR dengan primer universal yaitu 24F (5'AGAGTTTGATCCTGGCT-3') dan 1542R (5'AAGGAGGTGATCCAGCCGCA-3'). Kondisi PCR yang digunakan adalah: denaturasi $\left(94^{\circ} \mathrm{C} ; 30\right.$ detik), annealing $\left(52^{\circ} \mathrm{C} ; 1,5\right.$ menit) dan extension $\left(72^{\circ} \mathrm{C} ; 1\right.$ menit) dengan volume pervial sampel $25 \mu$ l. Produk PCR dipurifikasi dengan fenol:kloroform (Wasko et al., 2003). Sekuensing 16S rDNA dilakukan menggunakan sequencer model Perkin-Elmer ABI PRISM 3130 Genetic Analyzer (Applied Biosystem). Data sekuen dialignment dengan program CLUSTAL X (Thomson et al., 1994). Phylogenetic tree dikonstruksi dengan metoda neighbour-joining menggunakan program PHYLIP (Felsenstein, 1999). Nucleotide difference dan matriks similaritas dikonstruksi menggunakan program PHYDIT (Chun, 1999). 


\section{Hasil dan Pembahasan}

Berdasarkan hasil seleksi tingkat toleransi isolat terhadap TCMTB diketahui bahwa empat isolat (PK1, PK2, PK4 dan PK6) menunjukkan tingkat toleransi tinggi, karena masih mampu tumbuh pada kisaran konsentrasi 30-40 ppm dengan tidak membentuk zona jernih. Sedangkan tiga isolat lainnya (PK3, PK5 dan PK7) tampak membentuk zona jernih pada konsentrasi 30ppm, diameternya berkisar antara 2,5-6,3 mm (Tabel 1.).

Menurut Spain dan van Veld (1983) tingkat adaptasi suatu mikrobia terhadap senyawa xenobiotic berperan penting dalam menentukan kemampuannya mendegradasi senyawa tersebut di lingkungan. Hal ini berkaitan dengan kapasitas metabolik mikrobia dalam menggunakan xenobiotic sebagai substrat pertumbuhan yang sifatnya novel (van der Meer et al., 1992). Gaja dan Knapp (1997) melaporkan bahwa proses degradasi TCMTB diikuti oleh adanya penghasilan senyawa $\mathrm{NH}_{4}{ }^{+}$ dan $\mathrm{SO}_{4}{ }^{2}$ yang disertai dengan meningkatnya biomassa sel. Berdasarkan hal itu tampak bahwa keempat isolat berpotensi untuk mendegradasi TCMTB karena menghasilkan kedua senyawa tersebut (Tabel 2) meskipun kadar yang diperoleh rendah.

Hasil penelitian ini sesuai dengan hasil penelitian sebelumnya yang dilakukan oleh
Besse et al., (2001) dan De Wever et al., (1998). Menurut mereka hal ini kemungkinan disebabkan karena nitrogen dan sulfat diasimilasi sel atau diubah ke dalam bentuk senyawa lain selain $\mathrm{NH}_{4}{ }^{+}$dan $\mathrm{SO}_{4}{ }^{2-}$. Namun tiga diantaranya (PK2, PK4, PK6) terpilih berdasarkan kadar $\mathrm{NH}_{4}^{+}$yang dihasilkan dan waktu pelepasan yang lebih cepat, sedangkan kadar $\mathrm{SO}_{4}{ }^{2-}$ yang dihasilkan oleh ke-empat isolat tampak fluktuatif.

Setelah dianalisis, residu TCMTB yang terdapat dalam medium yang diinokulasi PK2, yang awalnya $40 \mathrm{ppm}$, menurun hingga 23,69 ppm (40,8\%). Penurunan ini lebih tinggi dibandingkan dengan dua isolat lainnya (PK4, PK6), yang hanya mampu menurunkan persentase TCMTB masing-masing 27,3\% dan $27,4 \%$ dengan masing-masing penurunan konsentrasi 29,07 ppm dan 29,04 ppm.

Berdasarkan hasil identifikasi isolat tingkat genus dengan metoda profile matching diketahui bahwa isolat unggul PK2 diidentifikasi sebagai anggota genus Pseudomonas (Tabel 3). Hasil ini didukung oleh identifikasi filetik secara molekular yaitu dengan konstruksi phylogenetic tree berdasarkan partial sequence $16 \mathrm{~S}$ rDNA dan diketahui bahwa isolat PK2 diidentifikasi sebagai anggota genus Pseudomonas (Gambar 1).

Tabel 1. Hasil uji toleransi isolat terhadap variasi konsentrasi TCMTB berdasarkan diameter zona yang terbentuk $(\mathrm{mm})$.

\begin{tabular}{cccccc}
\hline \hline \multirow{2}{*}{ Kode Isolat } & \multicolumn{5}{c}{ konsentrasi TCMTB (ppm) } \\
\cline { 2 - 6 } & $\mathbf{2 0}$ & $\mathbf{3 0}$ & $\mathbf{4 0}$ & $\mathbf{5 0}$ & $\mathbf{6 0}$ \\
\hline \hline PK1 & + & + & + & + & 1.0 \\
PK2 & + & + & + & 3.0 & 4.0 \\
PK3 & + & 3.0 & 4.0 & 3.0 & 4.0 \\
PK4 & + & + & 4.0 & 3.0 & 3.0 \\
PK5 & + & 2.5 & 2.5 & 3.0 & 5.0 \\
PK6 & + & + & + & 2.0 & 3.0 \\
PK7 & + & 4.0 & 6.0 & 6.0 & 6.3 \\
\hline \hline
\end{tabular}

Ket: + : tidak membentuk zona jernih. 
Tabel 2. Senyawa $\mathrm{NH}_{4}{ }^{+}$dan $\mathrm{SO}_{4}{ }^{2-}$ yang dihasilkan empat isolat terpilih setelah diinkubasikan pada suhu $37^{\circ} \mathrm{C}$ selama $168 \mathrm{jam}$.

\begin{tabular}{ccccccccc}
\hline \hline \multirow{2}{*}{ Jam Ke- } & \multicolumn{3}{c}{ Penghasilan $\mathbf{N H}_{\mathbf{4}}{ }^{+}(\mathbf{p p m})$} & \multicolumn{4}{c}{ Penghasilan $\mathbf{S O}_{\mathbf{4}}{ }^{2-}(\mathbf{p p m})$} \\
\cline { 2 - 9 } & PK1 & PK2 & PK4 & PK6 & PK1 & PK2 & PK4 & PK6 \\
\hline \hline 0 & 0 & 0 & 0 & 0 & 0 & 0 & 0 & 0 \\
24 & 0 & 0 & 0 & 0 & 0 & 0 & 0 & 0 \\
48 & 0 & 0 & 0 & 0 & 0,03 & 0 & 0 & 0,22 \\
72 & 0 & 0 & 0 & 0 & 0,56 & 0,14 & 0,26 & 0,1 \\
96 & 0 & 0 & 0,26 & 0,24 & 0,29 & 0,06 & 1,6 & 0,19 \\
120 & 0 & 0,55 & 0,54 & 0,51 & 0,5 & 0,26 & 0,17 & 1 \\
144 & 0,32 & 0,32 & 0,32 & 0,33 & 0,64 & 0,9 & 1,14 & 0,2 \\
168 & 0,23 & 0,227 & 0,229 & 0,23 & 0,61 & 0,61 & 0,35 & 0,61 \\
\hline \hline
\end{tabular}

Tabel 3. Profile matching identifikasi isolat unggul PK2 dengan genus acuan berdasarkan Bergey's Manual of Determinative Bacteriology (Holt et al., 1994).

\begin{tabular}{|c|c|c|}
\hline Unit Karakter & Genus Pseudomonas & PK2 \\
\hline Gram & negatif & negatif \\
\hline Motilitas & motil & motil \\
\hline Bentuk sel & batang pendek & batang pendek \\
\hline Katalase & + & + \\
\hline Oksidase & + & + \\
\hline Ukuran sel $(\mu \mathrm{m})$ & $0.5-1.0 \times 0.5-5.0$ & $0.5 \times 1.5$ \\
\hline Reduksi nitrat & + & + \\
\hline Kebutuhan $\mathrm{O}_{2}$ & aerob & aerob \\
\hline Ooptimum temperatur & NA & NA \\
\hline Pertumbuhan $\mathrm{pH}<4,5$ & - & - \\
\hline Pertumbuhan $41^{\circ} \mathrm{C}$ & + & + \\
\hline Pertumbuhan $4^{0} \mathrm{C}$ & + & + \\
\hline Hidrolisis gelatin & - & - \\
\hline Hidrolisis pati & - & - \\
\hline Endospora & NA & NA \\
\hline Sumber C : glukosa & $+/-$ & - \\
\hline$d$-xylose & - & - \\
\hline sukrosa & $+/-$ & - \\
\hline Susunan sel & NA & NA \\
\hline Pigmentasi koloni (NA) & NA & NA \\
\hline Penghasilan asam: glukosa & NA & NA \\
\hline$d$-xylose & NA & NA \\
\hline Pigmen fluoresen & $+/-$ & - \\
\hline Pigmen piosianin & $+/-$ & - \\
\hline
\end{tabular}

NA: Not Applicable 


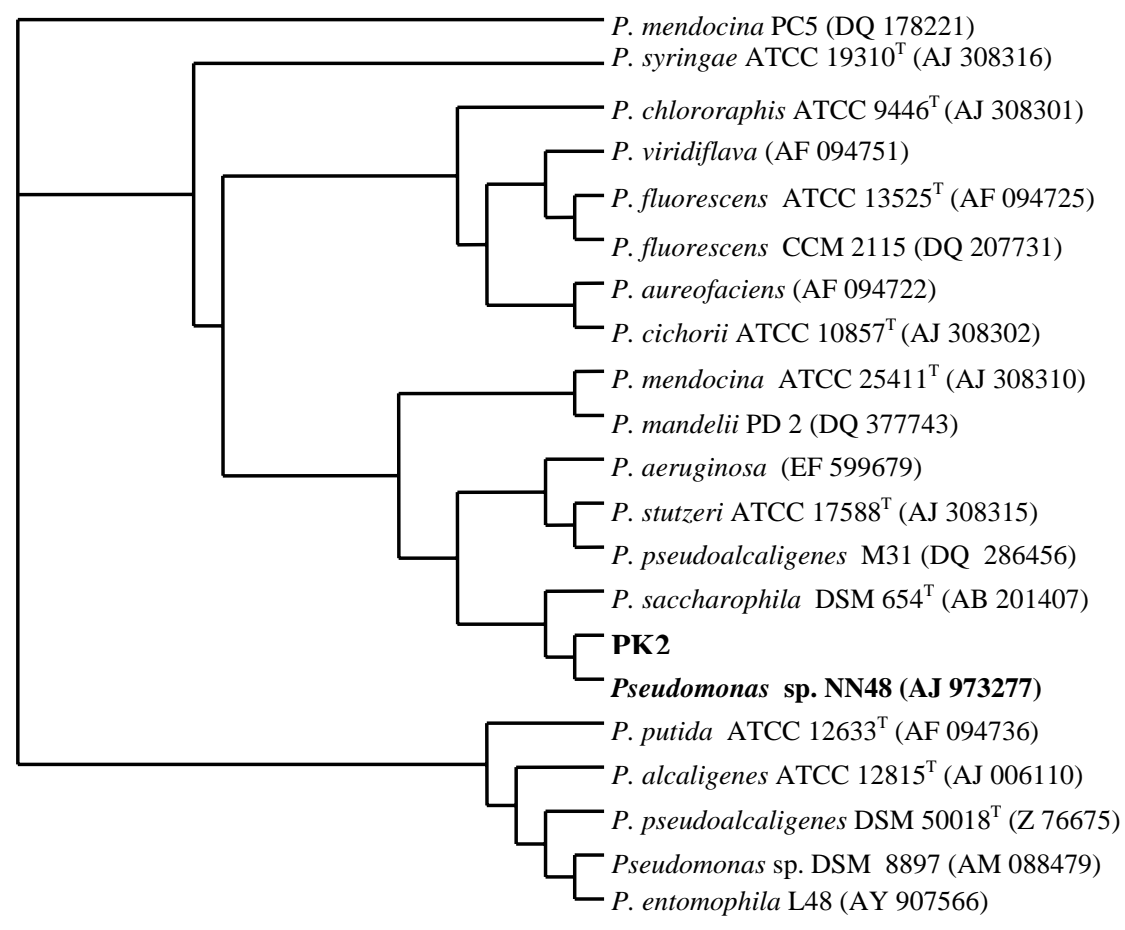

Gambar 1. Pohon filogeni yang dikonstruksi berdasarkan algoritma Neighbourjoining dengan menggunakan data sekuen 16S rDNA, menunjukkan hubungan kekerabatan antara isolat dengan strain acuan anggota genus Pseudomonas.

\section{Kesimpulan dan Saran}

\section{Kesimpulan}

Berdasarkan hasil penelitian dapat disimpulkan bahwa dari 7 isolat yang diuji terpilih 4 isolat yang menunjukkan toleransi tinggi terhadap TCMTB dengan kisaran 30ppm-40ppm yaitu PK1, PK2, PK4 dan PK6. Penghasilan $\mathrm{NH}_{4}^{+}$dan $\mathrm{SO}_{4}{ }^{2-}$ selama proses degradasi TCMTB dapat digunakan sebagai salah satu seleksi untuk mengetahui kemampuan isolat dalam mendegradasi TCMTB dan berdasarkan hal ini terseleksi tiga isolat yaitu PK2, PK4 dan PK6. Isolat PK2 merupakan isolat unggul dalam mendegradasi TCMTB dan berdasarkan karakteristik fenotipik dan molekular (sekuen 16S rDNA) isolat PK2 diidentifikasi sebagai anggota genus Pseudomonas.

\section{Saran}

Guna mengetahui kondisi optimum pertumbuhan isolat yang mendukung proses degaradasi TCMTB perlu dilakukan penelitian lebih lanjut antara lain melakukan optimasi $\mathrm{pH}$, suhu dan kecepatan agitasi. Disamping itu jalur degradasi yang terjadi perlu juga untuk ditelaah mendalam kaitannya dengan enzim yang berperanan dalam proses degradasi TCMTB. Isolat yang diketahui berpotensi dalam mendegradasi TCMTB perlu untuk diidentifikasi lebih lanjut hingga ke aras spesies dan kemungkinan untuk memperoleh isolat baru (novel species).

\section{Daftar Pustaka}

Birbir, M., Ozyaral, O., Johansson, C. and Ilgaz, A. 1994. Mold Strains Isolated From Unfinished and Finished Leather Goods and Shoes. J. of The American Leather Chemist Assosiation 89: 14-19.

Besse, P., Combourieu, B., Boyse, G., Sancelme, M., De Wever, H. and Delor, A.M. 2001. LongRange ${ }^{1} \mathrm{H}-{ }^{15} \mathrm{~N}$ Heteronuclear Shift Correlation at Natural Abundance: a Tool Study Benzothiazole Biodegradation by Two Rhodococcus Strains. Appll. and Enviro. Microbio. 67 (4): 1412-1417. 
Chun, J. 1999. PHYDIT (The Phylogenetic Molecular Sequence Editor) Version 3.0. User' Manual.

de Wever, H., Vereecken, K., Stolz, A. and Verachtert, H. 1998. Initial transformations in the Biodegradation of Benzothiazoles by Rhodococcus Isolates. Appll. and Enviro. Microbio. 64 (9): 3270-3274.

Ewing, D.R. 1999. Diminishing Return: Salmon Decline and Pesticides. Oregon Pesticide Education Network (OPEN). USA.

Felsenstein, J. 1999. PHYLIP (Phylogeny Inference Package) Version 3.5c. User' Manual.

Gaja, M.A. and Knapp, J.S. 1997. The Microbial Degradation of Benzothiazole. J. of Appll. Microbio. 83: 327-334.

Hanssen, H.W., Henderson, N.D. and Ward, J.E.H. 1991. A Review of The Environmental Impact and Toxic Effect of TCMTB. B.C. Environment Columbia.

Haroune, N., Combourieu, B., Besse, P., Sancelme, M., Reemtsa, T., Kloepfer, A., Diab, A., Knapp, J.S., Baumberg, S. and Delort, A.M. 2002. Benzothiazole Degradation by Rhodococcus pyridinovorans strain PA: Evidence of Catechol 1,2-Dioxygenase Activity. Appll. and Enviro. Microbio. 68: 6114-6120.

Holt, J.G., Krieg, N.R., Sneath, P.H.A., Staley, J.T. and Williams, S.T. 1994. Bergey's Manual of Determinative Bacteriology $9^{\text {nd }}$ ed. Williams and Wilkins. Baltimore.

Junker, F., Leisinger, T. and Cook, A.M. 1994. 3Sulfocatechol 2,3-dioxygenase and Dioxygenases in the Degradative Pathways of 2-aminobenzenesulphonic, benzenesulphonic and 4-toluenesulphonic acids in Alcaligenes sp. Strain O-1. Microbiology 140: 1713-1722.
Kirouani, H.H. 2003. Microbial and Photolytic Degradation of Benzothiazoles in Water and Wastewater. Thesis. Technical University of Berlin. http://edocs.tu-berlin.de/diss/ 2003/kirouani hafida.pdf. 09/07/2005.

Spain, J.C. and Van Veld, P.A. 1983. Adaptation of Natural Microbial Communities to Degradation of Xenobiotic Compound: Effects of Concentration, Exposure Time, Inoculum, and Chemical sStructure. Appll. and Enviro. Microbio. 45 (2): 428-435.

Thomson, J.D., Higgins, D.G. and Gibson, T.J. 1994. CLUSTAL X Version 1.6. User' Manual.

van der Meer, J.R., De Vos, W.M., Harayama, S. and Zehnder, A.J.B. 1992. Molecular Mechanism of Genetic Adaptation to Xenobiotic Compound. Microbiological Reviews 56 (4): 677-694.

Wasko, A.P., Martins, C., Oliveira, C. and Foresti, F. 2003. Non-destructive Genetic Sampling in Fish. An improved Method for DNA Extraction from Fish Fins and Scales. Hereditas. 138: 161-165.

Yapici, M.B. and Karaboz, I. 1997. The Effect of Two anti-Fungal Compounds on the Growth of Molds that Frequently Appear on Tanned Leather. J. of The American Leather Chemist Assosiation. 92: 38-45. 